Institute of
Medicinal Plants

Research Article

\title{
Effects of ethanolic extract of Artemisia persica on scopolamine-induced cognitive impairment and anxiety in rats
}

\author{
Zahra Rabiei ${ }^{1}$, Rayhaneh Joodaki², Mahbubeh Setorki ${ }^{2}$,* \\ ${ }^{I}$ Medical Plants Research Center, Basic Health Sciences Institute, Shahrekord University of Medical Sciences, \\ Shahrekord, Iran \\ ${ }^{2}$ Department of Biology, Izeh Branch, Islamic Azad University, Izeh, Iran
}

\begin{tabular}{|c|c|}
\hline ARTICLE INFO & ABSTRACT \\
\hline $\begin{array}{l}\text { Keywords: } \\
\text { Artemisia persica } \\
\text { Anxiety } \\
\text { Avoidance memory }\end{array}$ & $\begin{array}{l}\text { Background: Artemisia persica is used as an antiseptic, carminative, appetizer, } \\
\text { antiparasitic, and antipyretic agent as well as to relieve fascial pains, and in the past, } \\
\text { was used to relieve neuropathic pain and facilitate uterine contractions during } \\
\text { childbirth. Objective: The aim of this study was to investigate the antioxidant } \\
\text { potential and effects of } A \text {. persica on scopolamine-induced cognitive impairments and } \\
\text { anxiety. Methods: In this experimental study, } 50 \text { male rats were randomly divided } \\
\text { into } 5 \text { groups of } 10 \text { each, including control group, scopolamine }(0.7 \mathrm{mg} / \mathrm{kg} \text {, } \\
\text { intraperitoneal injection) group, and three groups receiving scopolamine and } \\
\text { ethanolic Artemisia persica extract (100, } 200 \text {, and } 400 \mathrm{mg} / \mathrm{kg}) \text {. After three weeks of } \\
\text { treatment, behavioral tests including passive avoidance memory, plus maze test, and } \\
\text { rotarod test were conducted. The level of malondialdehyde and the antioxidant } \\
\text { capacity of the serum and brain in the rats were measured. Results: Treatment with } \\
\text { A. persica extract at } 100,200 \text {, and } 400 \mathrm{mg} / \mathrm{kg} \text { in rats receiving scopolamine caused a } \\
\text { significant increase in secondary latency in shuttle Box test (P < } 0.01) \text {. Treatment of } \\
\text { rats receiving scopolamine with } A \text {. persica extract at } 100 \text {, 200, and } 400 \text { mg/kg } \\
\text { significantly decreased the time elapsed in closed arms and significantly increased the } \\
\text { time elapsed in the open arms in plus maze test (P < } 0.05) \text {. Conclusion: The results } \\
\text { of this study indicate that } A \text {. persica can act as a potent neuropharmacologic agent } \\
\text { against cognitive impairment by modulating cholinergic activity and neuritis in the rat } \\
\text { hippocampus. }\end{array}$ \\
\hline
\end{tabular}

\section{Introduction}

Alzheimer's disease (AD) is the most common neurological disorder and accounts for about two thirds of all dementia cases. AD is associated with cognitive and behavioral disorders. Noncognitive symptoms such as distress, aggression, depression, anxiety and insanity are seen in most patients with $\mathrm{AD}[1]$.

Abbreviations: AD, Alzheimer disease; AChE, Acetylcholinesterase; SOD, Superoxide dismutase; GPx, Glutathione peroxidase; CAT, Catalase; ChAT, Choline acetyltransferase; BDNF, brain-derived neurotrophic factor

* Corresponding author: doctor.setorgi@gmail.com

doi: $10.29252 / \mathrm{jmp} .1 .73 .133$

Received 15 May 2018; Received in revised form 9 July 2019; Accepted: 9 July 2019

(C) 2020. Open access. This article is distributed under the terms of the Creative Commons Attribution-NonCommercial 4.0 International License (https://creativecommons.org/licenses/by-nc/4.0/) 
The neurochemical analyses of brain tissues in AD patients have shown a significant decrease in the cortical cholinergic neurons, as well as cholinergic defects in the cortex and the hippocampus [2].

Acetylcholinesterase (AChE) is a goal in the treatment of $\mathrm{AD}$, and inhibiting the activity of this enzyme to maintain the level of AChE in neuronal synapses has positive effects in $\mathrm{AD}$ patients. Evidence suggests that AChE inhibitors reduce the excess metabolism of synaptic $\mathrm{ACh}$, and high levels of $\mathrm{ACh}$ in the synaptic cleft of post-synaptic movements. Memory deficits caused by cholinergic deficiency are associated with increased oxidative stress following scopolamine treatment [3].

However, a strong correlation was observed between scopolamine-induced memory deficits and oxidative stress in the hippocampus in a rat model of scopolamine-induced cognitive impairments. Reduced activity of antioxidant enzymes such as superoxide dismutase (SOD), glutathione peroxidase (GPx), and catalase (CAT) in the early stages of $\mathrm{AD}$ has been reported [5, 6]. Scopolamine is a muscarinic receptor antagonist, which causes transient memory deficit and induces a pattern similar to that of AD in animals [7].

Due to the high prevalence of central nervous system disorders, including $\mathrm{AD}$, and the lack of definite treatment for these diseases, as well as the side effects due to chemical drugs and their inappropriate use, studies are being conducted with the aim of finding compounds with appropriate efficacy [8].

Dermaneh Irani, botanically called Artemisia persica, is one of the most valuable medicinal plants. A. persica is herbaceous, perennial, and self growing plant of the Cichorium family, that reaches a height of $90-120 \mathrm{~cm}$, and grows in snowy highlands of Iran. Its compounds include essential oils, minerals, resins, santonin, volatile fatty acids, and artemisinin. A. persica is used as antiseptic, carminative, appetizer, antiparasitic, and antipyretic agent as well as to relieve fascial pains, and in the past, was used to relieve neuropathic pain and facilitate uterine contractions during childbirth [9].

In vitro studies have shown antioxidant [10] anticancer [11], anti-bacterial, antifungal [12], antiviral [13] and antimalarial [14] effects of this plant.

Although the protective effects of A. persica on the nervous system have not yet been investigated, the protective effects of other plants of the Artemisia genus on the nervous system have been shown, for example, the activity of monoamine oxidase inhibitor in the rat brain by Artemisia vulgaris [15], the protective effects of Artemisia absinthium against global brain ischemia [16], the protective effects of Artemisia asiatica against the damage to $\mathrm{PC} 12$ by the amyloid plaque [17], and the benzodiazepinelike activity of the Artemisia herba-alba flavonoids on the GABA receptors [18].

Although the identified compounds from A. persica had significant activity in $\mathrm{AD}$, there is no study clarifying the possible cognitiveenhancing and antioxidant potentials of the extract from A. persica in a rat model of scopolamine. Therefore, we investigated the possible memoryenhancing effects of the extract from A. persica in memory-impaired rats and its possible mechanism on the levels of biochemical parameters in the rat hippocampus of the scopolamine model.

\section{Materials and Methods}

\subsection{Preparation of Artemisia persica Extract}

Dried $A$. persica was purchased from the groceries of the Izeh city, and after being identified as the plant of interest by a botanist, was registered at the Herbarium of Islamic Azad 
University, Izeh Branch (herbarium number: 566). The dried leaves were pulverized and then placed in $70 \%$ ethanol.

The glass flask containing the plant was placed on a magnetic shaker and then left at room temperature for 72 hours. The contents were then filtered and the solution was kept at $37{ }^{\circ} \mathrm{C}$ to allow water and alcohol to evaporate so that the extract was dried then kept at $-20{ }^{\circ} \mathrm{C}$ until use (yielded 32\%). A. persica extract was dissolved in saline.

\subsection{Evaluation of in vitro antioxidant activity of} Artemisia persica

DPPH radical scavenging activity: Briefly, 1 $\mathrm{mL}$ of $0.1 \mathrm{mM}$ DPPH solution (prepared in $95 \%$ ethanol) was added to $1 \mathrm{~mL}$ of extract at different concentrations $(50-300 \mu \mathrm{g} / \mathrm{mL})$ and incubated for $15 \mathrm{~min}$ in the darkness at room temperature, and then the absorbance was read at $517 \mathrm{~nm}$ against blank sample. The blank sample was prepared using distilled water instead of the extract. DPPH radical scavenging activity was calculated using the following formula:

DPPH radical scavenging activity $(\%)=\left[\left(\mathrm{A}_{\text {blank }}-\right.\right.$

$$
\left.\left.\mathrm{A}_{\text {sample }}\right) / \mathrm{A}_{\text {blank }}\right] \times 100
$$

$\mathrm{IC}_{50}$ value obtained by plotting a graph of concentration (X-axis) against the percentage of inhibition (Y-axis) [19].

\subsection{Grouping and treatment of rats}

Male rats were kept under the same conditions $\left(21 \pm 2{ }^{\circ} \mathrm{C}, 12\right.$ hour light/12 hour darkness cycle, and free access to the same water and food).

The male Wistar rats were randomly assigned into 5 groups of 10 each. The control group was injected with normal saline $(1 \mathrm{mg} / \mathrm{kg})$ for 21 days.

The scopolamine group received scopolamine at $0.7 \mathrm{mg} / \mathrm{kg}$ for 21 days.

Journal of Medicinal Plants
The experimental groups received scopolamine and then the A. persica extract at 100,200 and $400 \mathrm{mg} / \mathrm{kg}$ through intraperitoneal injection for 21 days.

After the treatment period was completed, behavioral tests were conducted. Then, the samples of blood and brain tissue were collected as the rats were under deep anesthesia, and then were prepared for later examinations.

\subsubsection{Passive avoidance memory}

Passive avoidance memory was measured by shuttle box. This apparatus has a bright chamber connected to a dark chamber by a guillotine door. Electric shocks are exerted to a conductive metal grid on the floor of the apparatus by a separate stimulus. This test was performed on each rat for four consecutive days. On the first two days, rats were individually allowed to freely explore the apparatus for $5 \mathrm{~min}$. On the third day, an acquisition test was conducted. Rats were left in the bright chamber and, after 2-minute acclimatization, the guillotine door was opened and after the rat entry into the dark chamber, it was closed and an electrical shock ( $2 \mathrm{~mA} / \mathrm{second}$ ) was exerted to rat and the latency to enter the dark chamber was recorded as initial latency. Twenty-four hours later, each rat was placed in the bright chamber and latency to enter the dark chamber was measured as secondary latency (up to 60 seconds) [20].

\subsubsection{Rotarod performance test}

The ability to maintain balance and motor resistance was investigated using rotarod. This apparatus has a rod that rotates at a speed of 0-40 rpm. The apparatus also has a belt and the speed of the rod can be adjusted by changing the belt position. First, the animal was placed on the rotating rod of the apparatus and trained to walk on it according to the main protocol (10 rpm and 
$7 \mathrm{rpm}^{2}$ acceleration). Thirty min later, the rat was again placed on the rod and the time to maintain balance and resist rod movement was recorded. The maximum time for each animal in this test was considered to be $300 \mathrm{sec}$ [20].

\subsubsection{Elevated plus maze (EPM) test}

An apparatus called elevated plus maze was used to measure anxiety. This apparatus has two opposite open arms, two opposite closed arms, and a central sheath elevated $50 \mathrm{~cm}$ above the floor. This test was performed in a relatively dark, silent chamber, and each animal was placed gently in the center of the device facing the open arm and allowed to explore for $5 \mathrm{~min}$. The number of entries and time spent in each arm were recorded [20].

\subsection{Measuring serum MDA level}

Briefly, $0.5 \mathrm{~g}$ of thiobarbituric acid was mixed with $80 \mathrm{ml}$ of acetic acid $20 \%$ and the $\mathrm{pH}$ of the resulting mixture set at 3.5 by adding sodium hydroxide and its volume diluted with $100 \mathrm{ml}$ acetic acid $20 \%$. $100 \mu$ l of serum sample was mixed with $100 \mu$ l of SDS solution $1.8 \%$ and $2.5 \mathrm{ml}$ of stock solution. Samples were placed in water bath for 1 hour, and then cooled and centrifuged at $4000 \mathrm{rpm}$. The optical absorbance of the supernatant was read at 523-nm wavelength [21].

\subsection{Measuring brain MDA level}

One $\mathrm{g}$ of brain tissue was homogenized in cooled $\mathrm{KCl} 2.5 \%$ at 1:10 (weight-volume) and incubated in a metabolic incubator shaker at $37 \pm 1{ }^{\circ} \mathrm{C}$ for $60 \mathrm{~min}$. Then, $1 \mathrm{ml}$ of tetrachloroacetic acid $5 \%$ and $1 \mathrm{ml}$ thiobarbituric acid $67 \%$ were added and finely mixed. The solution of each vial was centrifuged at $2000 \mathrm{rpm}$ for $15 \mathrm{~min}$. Then, the supernatant was transferred to another tube and placed in water bath. After 10 minutes, test tubes were cooled and optical absorbance read at 535-nm wavelength [21].

\subsection{Measuring serum and brain ferric reducing ability of plasma (FRAP)}

Three solutions consisting of 1: a buffer $(1.55 \mathrm{ml}$ of sodium acetate and $8 \mathrm{ml}$ of concentrated acetic acid diluted with distilled water to a final volume of $500 \mathrm{ml}$ ), 2: iron chloride solution [270 mg of iron (III) chloride diluted with distilled water to a final volume of $50 \mathrm{ml}$ ], and 3: triazine solution (47 $\mathrm{mg}$ of triazine dissolved in $40 \mathrm{ml}$ of $40 \mathrm{mM}$ hydrochloric acid) were used to measure the antioxidant capacity in serum and brain. Stock solution was prepared by adding $10 \mathrm{ml}$ of the solution 1 , one $\mathrm{ml}$ of the solution 2 , and one $\mathrm{ml}$ of the solution 3 . Twenty five $\mu$ l of serum or brain homogenate was added to $1.5 \mathrm{ml}$ of stock solution and the resulting solution left at $37{ }^{\circ} \mathrm{C}$ for 10 minutes. Optical absorbance was then read at 593 nm wavelength [21].

\subsection{Statistical analysis}

Data were analyzed using SPSS version 20. Analysis of Variance (ANOVA) followed by Tukey test used to identify statistical differences between means. All data were presented as mean $\pm \mathrm{SD}$ and $\mathrm{P}$ value less than 0.05 was considered statistically significant.

\section{Results}

In the present study antioxidant activity of Artemisia persica extract was evaluated and the results showed that Artemisia persica has a strong removing activity against DPPH-free radicals ( $\mathrm{IC}_{50}$ $=98.80 \mu \mathrm{g} / \mathrm{ml}$ ).

The results on the duration of the initial and secondary latency in the passive avoidance memory test in the studied groups are illustrated in Fig. 1. 


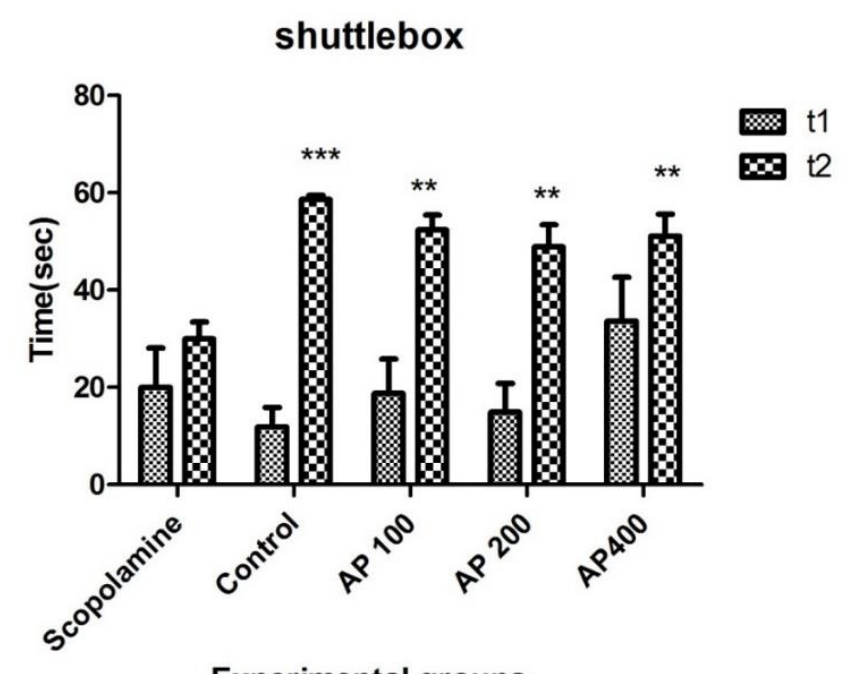

\section{Experimental groups}

Fig. 1. Comparison of the duration of the primary (t1) and secondary (t2) latency in the passive avoidance memory test between studied groups; $* * *$ significant difference $(\mathrm{P}<0.001)$; $* *$ significant difference $(\mathrm{P}<0.01)$; AP: Artemisia persica

Table 1. Comparison of the mean ( \pm standard deviation) duration of balance maintenance in Rotarod test between studied groups

\begin{tabular}{cc}
\hline Experimental groups & Time on rotarod \\
\hline scopolamine & $24.88 \pm 13.24$ \\
control & $50.75 \pm 25.18$ \\
Scopolamine + AP100 & $18.71 \pm 9.3$ \\
Scopolamine + AP200 & $53.43 \pm 50.67$ \\
Scopolamine + AP400 & $51.14 \pm 35.01$ \\
\hline
\end{tabular}

According to the results, there was no significant difference in the primary latency to enter the dark chamber between the studied groups $(F=1.398)$. Secondary latency duration was significantly lower in the scopolamine receiving group $(\mathrm{F}=8.103)$ than in the control group $(\mathrm{P}<0.001)$. Treatment with $A$. persica extract at 100, 200 and $400 \mathrm{mg} / \mathrm{kg}$ significantly increased the latency duration in the rats given scopolamine $(\mathrm{P}<0.01)$.

The results regarding the duration of balance maintenance in the Rotarod test in the studied groups are shown in Table 1. According to the results, there was no significant difference between the studied groups $(\mathrm{F}=2.226)(\mathrm{P}>0.05)$.

As illustrated in Fig. 2, scopolamine treatment in rats caused a significant increase in the time elapsed in the closed arms $(\mathrm{F}=5.118)$ and a significant decrease in the time elapsed in the open arms $(\mathrm{F}=31.91)$ of the elevated plus-maze device. Treatment with $A$. persicaextract at 200 and $400 \mathrm{mg} / \mathrm{kg}$ of in the scopolamine receiving rats caused a significant decrease in elapsed time in closed arms and a significant increase in elapsed time in open arms in the elevated plusmaze $(\mathrm{P}<0.05)$.

According to the Table 2, scopolamine treatment significantly increased MDA levels in the serum $(\mathrm{F}=10.44)$ and brain $(\mathrm{F}=12.73)$ tissue in the rats $(\mathrm{P}<0.01)$. The treatment with the $A$. persica extract at the three doses did not cause a significant decrease in the serum and brain MDA levels compared to the scopolamine receiving group. 
According to the results of Table 3, the antioxidant capacity of the brain $(\mathrm{F}=35.75)$ and serum $(F=13.89)$ significantly decreased in the rats treated with scopolamine. The treatment with

A

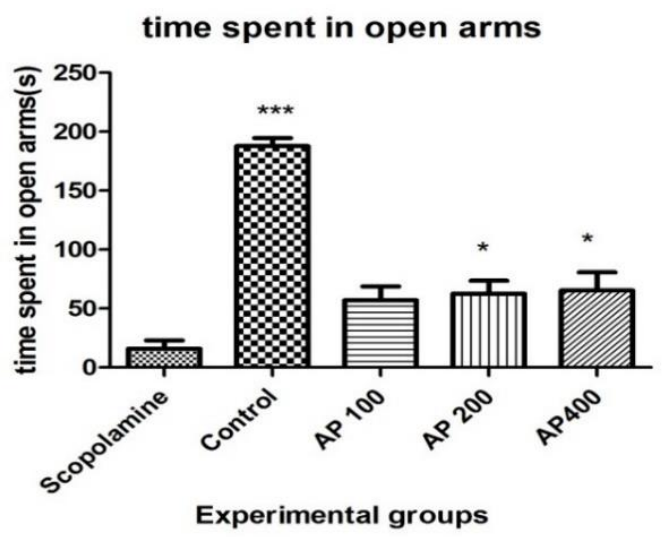

the A. persica extract at the three doses did not cause a significant increase in the antioxidant capacity of the serum and brain tissues compared to the group treated with scopolamine.

B

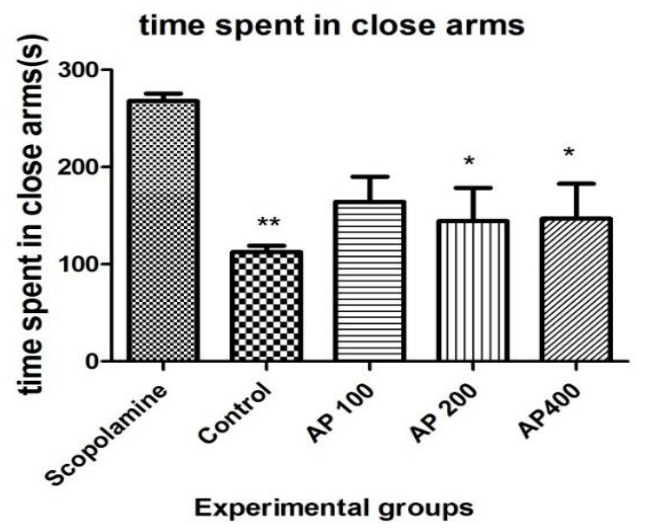

Fig. 2. Comparison of the time elapsed in the open (A) and closed (B) arms in the elevated plus-maze device between studied groups; *** significant difference $(\mathrm{P}<0.001)$; ** significant difference $(\mathrm{P}<0.01)$, * significant difference (P < 0.05). AP: Artemisiapersica

Table 2. Comparison of the mean ( \pm standard deviation) values of brain and serum malondialdehyde levels between studied groups

\begin{tabular}{ccc}
\hline Experimental groups & \multicolumn{2}{c}{ MDA } \\
\cline { 2 - 3 } & Serum & Brain \\
\hline Scopolamine & $362.1 \pm 95.14$ & $244.4 \pm 57.96$ \\
Control & $241.6 \pm 27.51^{* * *}$ & $148.3 \pm 33.55^{* *}$ \\
Scopolamine + AP100 & $339.7 \pm 34.90$ & $243.3 \pm 29.31$ \\
Scopolamine + AP200 & $292.1 \pm 68.46$ & $220.9 \pm 56.22$ \\
Scopolamine + AP400 & $439.4 \pm 54.04$ & $302.5 \pm 35.05$ \\
\hline
\end{tabular}

${ }^{{ }^{*} \text { Significant difference }(\mathrm{P}<0.01)}$

Table 3. Comparison of mean ( \pm standard deviation) values of antioxidant capacity of brain and serum between studied groups

\begin{tabular}{ccc}
\hline \multirow{2}{*}{ Experimental groups } & \multicolumn{2}{c}{ Antioxidant capacity } \\
\cline { 2 - 3 } & Serum & Brain \\
\hline Scopolamine & $166.1 \pm 47.34$ & $241.5 \pm 16.23$ \\
Control & $453.1 \pm 142.9^{* * * *}$ & $364.3 \pm 34.30^{* * *}$ \\
Scopolamine + AP100 & $163.7 \pm 69.14$ & $232.9 \pm 17.5$ \\
Scopolamine + AP200 & $256.4 \pm 89.77$ & $265 \pm 61.68$ \\
Scopolamine+ AP400 & $203.3 \pm 34.66$ & $147.6 \pm 34.55$ \\
\hline
\end{tabular}

*** Significant difference $(\mathrm{P}<0.001)$ 


\section{Discussion}

In this study, the neuroprotective effects of ethanol extract of $A$. persica on scopolamineinduced learning and memory disorders were investigated. Treatment of rats with successive injections of scopolamine for 21 days resulted in a significant decrease in the secondary latency in the passive avoidance memory test. Scopolamine treatment also improved the anxiety behaviors in the plus maze test. A. persica extract significantly improved memory and anxiety in animals receiving scopolamine. Studies have shown that memory disorders caused by injection of scopolamine are associated with damage to cholinergic neurons and decreased levels of acetylcholine in the brain tissue.

A possible mechanism by which $A$. persica extract can improve memory and learning disorders may be increase in the sensitivity of cholinergic receptors in the brain or a decrease in AChE activity. The memory formed in the hippocampus is dependent on an increase in the level of extracellular acetylcholine (ACh). In addition, synaptic cholinergic transmission is impaired by the overexpression of acetylcholinesterase and decreased acetylcholine levels [22].

Studies have shown that Artemisia has potent anti-acetylcholinesterase properties in vitro [23]. A. persica has also been reported to increase the level of memory and learning through nicotinic and muscarinic receptors in human cortical tissue [24].

Studies have also shown that daily injection of scopolamine in rats with memory and learning impairment reduces the activities of choline acetyltransferase (ChAT) and brain-derived neurotrophic factor (BDNF) in the hippocampus [25]. BDNF is a protein that plays an important role in neuroprotection, neurogenicity, and synaptic plasticity, as well as in motor learning [26].

The level of this factor serves as a predictor of the development of neurodegenerative diseases, including AD [27].

Studies have shown that the ethanol extract of Artemisia increases the level of BDNF in the brain [28]. It seems that this plant can improve cognitive and behavioral disorders by affecting the factors that are effective on neurogenicity and synaptic plasticity.

Scopolamine impairs memory and learning by increasing oxidative stress in the entire brain tissue, as well as in specific structures related to memory and learning. Scopolamine also eliminates the metabolism of low molecular weight antioxidants, especially glutathione, and exacerbates the lipid peroxidation in the brain tissue, which makes the brain susceptible to ROS-induced damage due to the high concentrations of unsaturated fatty acids with high oxidizing properties, such as arachidonic acid and docosanoic acid [21].

In the present study, injection of scopolamine caused a significant reduction in the antioxidant capacity of brain and serum and a significant increase in MDA level that is a lipid peroxidation marker. In the study of Rashidchet al. (2010), the antioxidant effects and phenolic and flavonoid contents of the methanol extract of Artemisia persica were evaluated. The antioxidant activity of the extract in inhibiting DPPH free radicals was also determined.

In addition, the activity of the plant extract in inhibiting the oxidation of sunflower oil was determined by free fatty acid tests and lipid peroxidation marker. The results of these experiments showed that the plant extract had a strong antioxidant activity. The phenolic and flavonoid contents of the extract of the plant were 407 and $308 \mathrm{mg} / \mathrm{g}$, respectively [29]. 
The results of antioxidant tests on the A. persica extract in this study confirmed that the plant had a high antioxidant property. The results regarding serum and brain tissue antioxidant capacity indicated that the extract did not have a significant effect on oxidative stress parameters of the serum and brain tissues and cognitive impairments might be improved through other mechanisms.

\section{Conclusion}

A. persica is found only in Iran and is used for a wide spectrum of purposes in traditional medicine. However, few studies have been conducted on neuroprotective effects of the plant in animal models as well as in clinical trials. There is very limited information on the plant's active ingredients and the mechanism of its neuroprotective effects, necessitating further research on this subject. A possible mechanism by which $A$. persica extract can improve memory

\section{References}

1. Takeda S, Sato N and Morishita R. Systemic inflammation, blood-brain barrier vulnerability and cognitive/non-cognitive symptoms in Alzheimer disease: relevance to pathogenesis and therapy. Frontiers in Aging Neuroscience 2014; 6: 171.

2. Savonenko AV, Melnikova T, Hiatt A, Li T, Worley PF, Troncoso JC and et al. Alzheimer's therapeutics: translation of preclinical science to clinical drug development. Neuropsychopharmacol. 2012; 37 (1): 261.

3. Aydin E, Hritcu L, Dogan G, Hayta S and Bagci E. The effects of inhaled Pimpinellaperegrina essential oil on scopolamine-induced memory impairment, anxiety, and depression in laboratory rats. Molecular Neurobiol. 2016; 53 (9): 6557-67. and learning disorders may be increase in the sensitivity of cholinergic receptors in the brain or a decrease in AChE activity.

\section{Author contributions}

Zahra Rabei conceived and extracted the data, revised the paper, Mahbubeh Setorki designed the study, analyzed the data and wrote the manuscript. Reyhaneh Joudaki performed all testes.

\section{Conflict of interest}

The authors declare that there is no conflict of interest. The authors alone are responsible for the accuracy and integrity of the paper content.

\section{Acknowledgements}

The authors would like to thank the staff of laboratory of Islamic Azad University of Izeh, for technical support to this work.

4. Rahnama S, Rabiei Z, Alibabaei Z, Mokhtari S, Rafieian-kopaei M and Deris F. Anti-amnesic activity of Citrus aurantium flowers extract against scopolamine-induced memory impairments in rats. Neurological Sciences 2015; 36 (4): 553-60.

5. Boonruamkaew $\mathrm{P}$, Chonpathompikunlert $\mathrm{P}$, Vong LB, Sakaue S, Tomidokoro Y, Ishii K and et al. Chronic treatment with a smart antioxidative nanoparticle for inhibition of amyloid plaque propagation in $\mathrm{Tg} 2576$ mouse model of Alzheimer's disease. Scientific Reports 2017; 7 (1): 3785 .

6. Dolatabadi HRD, Reisi P, Malekabadi HRA, Alaei $\mathrm{H}$ andPilehvarian AA. Effects of folic acid on passive avoidance learning and memory in rat Alzheimer model by intracerebroventricular injection of Streptozotocin. Journal of Isfahan Medical School 2010; 28 (112): 647-655. 
7. Caine ED, Weingartner $\mathrm{H}$, Ludlow CL, Cudahy EA and Wehry S. Qualitative analysis of scopolamine-induced amnesia. Psychopharmacol. 1981; 74 (1): 74-80.

8. Ahmad A, Ramasamy K, Jaafar SM, Majeed ABA and Mani V. Total isoflavones from soybean and tempeh reversed scopolamineinduced amnesia, improved cholinergic activities and reduced neuroinflammation in brain. Food and Chemical Toxicol. 2014; 65: 120-8.

9. Masoudi S, Rustaiyan A and Vahedi M. Volatile oil constituents of different parts of Artemisia chamaemelifolia and the composition and antibacterial activity of the aerial parts of A. turcomanica from Iran. Natural Product Communications 2012; 7 (11): 1519-22.

10. Ahmadvand $H$, Amiri $H$, Dalvand $H$, Bagheri $S$ and et al. Various antioxidant properties of essential oil and hydroalcoholic extract of Artemisapersica. Birjand Univ. Med. Sci. 2014, 20 (4): 416-424.

11. Taghizadeh Rabe SZ, Mahmoudi M, Ahi A and Emami SA. Antiproliferative effects of extracts from Iranian Artemisia species on cancer cell lines. Pharmaceutical Biol. 2011; 49 (9): 962-9.

12. Ramezani M, Fazli-Bazzaz B, SaghafiKhadem $F$ andDabaghian A. Antimicrobial activity of four Artemisia species of Iran. Fitoterapia 2004; 75 (2): 201-3.

13. Karamoddini MK, Emami SA, Ghannad MS, Sani EA and Sahebkar A. Antiviral activities of aerial subsets of Artemisia species against Herpes Simplex virus type 1 (HSV1) in vitro. Asian Biomedicine 2011; 5 (1): 63-8.

14. Ramazani A, Sardari S, Zakeri S and Vaziri B. In vitro antiplasmodial and phytochemical study of five Artemisia species from Iran and in vivo activity of two species. Parasitology Res. 2010; 107 (3): 593-9.

15. Lee S-J, Chung H-Y, Lee I-K, Oh S-U andYoo I-D. Phenolics with inhibitory activity on mouse brain monoamine oxidase (MAO) from whole parts of Artemisia vulgaris $\mathrm{L}$ (Mugwort). Food Science and Biotechnol. 2000; 9 (3): 179-82.

16. Bora KS and Sharma A. Neuroprotective effect of Artemisia absinthium L. on focal ischemia and reperfusion-induced cerebral injury. $J$. Ethnopharmacol. 2010; 129 (3): 403-9.

17. Heo H-j, Cho H-Y, Hong B, Kim H-K, Kim E$\mathrm{k}$, Kim B-G and et al. Protective effect of 4', 5dihydroxy-3', 6, 7-trimethoxyflavone from Artemisia asiatica against $\mathrm{A} \beta$-induced oxidative stress in $\mathrm{PC} 12$ cells. Amyloid. 2001; 8 (3): 194-201.

18. Salah SM and Jäger AK. Two flavonoids from Artemisia herba-alba Asso with in vitro GABAA-benzodiazepine receptor activity. $J$. Ethnopharmacol. 2005; 99 (1): 145-6.

19. Gülçin İ. Antioxidant activity of caffeic acid (3, 4-dihydroxycinnamic acid). Toxicol. 2006; 217 (2-3): 213-20.

20. Kwon S-H, Lee H-K, Kim J-A, Hong S-I, Kim H-C, Jo T-H and et al. Neuroprotective effects of chlorogenic acid on scopolamineinduced amnesia via anti-acetylcholinesterase and anti-oxidative activities in mice. European J. Pharmacol. 2010; 649 (1-3): 210-7.

21. El-Sherbiny DA, Khalifa AE, Attia AS and Eldenshary EE-DS. Hypericumperforatum extract demonstrates antioxidant properties against elevated rat brain oxidative status induced by amnestic dose of scopolamine. Pharmacology Biochemistry and Behavior 2003; 76 (3-4): 525-33.

22. Cohen J, Zimmerman G, Melamed-Book N, Friedman A, Dori A and Soreq H. Transgenic inactivation of acetylcholinesterase impairs homeostasis in mouse hippocampal granule cells. Hippocampus 2008; 18 (2): 182-92.

23. Shoaib M, Shah I, Ali N and Shah SWA. In vitro acetylcholinesterase and butyrylcholinesterase inhibitory potentials of 
essential oil of Artemisia macrocephala. Bangladesh J. Pharmacol. 2015; 10: 87-91.

24. Wake G, Pickering A, Lewis R, Wilkins R and Perry E. CNS acetylcholine receptor activity in European medicinal plants traditionally used to improve failing memory. J. Ethnopharmacol. 2000; 69 (2): 105-14.

25. Lee B, Sur B, Shim J, Hahm D-H and Lee H. Acupuncture stimulation improves scopolamineinduced cognitive impairment via activation of cholinergic system and regulation of BDNF and CREB expressions in rats. BMC Complementary and Alternative Medicine 2014; 14 (1): 338.

26. Vaynman S, Ying Z and Gomez-Pinilla F. Hippocampal BDNF mediates the efficacy of exercise on synaptic plasticity and cognition. European J. Neuroscience 2004; 20 (10): 258090.

27. Komulainen $P$, Pedersen $M$, Hänninen $T$, Bruunsgaard H, Lakka TA, Kivipelto $M$ and et al. BDNF is a novel marker of cognitive function in ageing women: The DR's EXTRA Study. Neurobiology of Learning and Memory 2008; 90 (4): 596-603.

28. Li Y and Ohizumi Y. Search for constituents with neurotrophic factor-potentiating activity from the medicinal plants of Paraguay and Thailand. Yakugaku Zasshi 2004; 124 (7): 417 24.

29. Rashidch A, Qureshi MZ, Raza SA, William $\mathrm{J}$ and Arshad M. Quantitative Determination of Antioxidant Potential of Artemisia persica Analele UniversităŃNii din Bucuresti-Chimie (serie nouă). 2014; 19 (1): 23-30.

How to cite this article: Rabiei Z, Joodaki R,
Setorki M. Effects of ethanolic extract of
Artemisia persica on scopolamine-induced
cognitive impairment and anxiety in rats.
Journal of Medicinal Plants 2020; 19(73):
133-142.
doi: $10.29252 /$ jmp.1.73.133




\title{
بر اختلالات شناختى و اضطراب (Artemisa persica)
}

\author{
بررسى اثرات عصاره اتانولى درمنهى ايرانى \\ ناشى از اسكويولامين در موشهاى اترات صحرايى

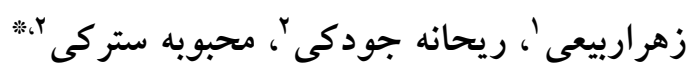

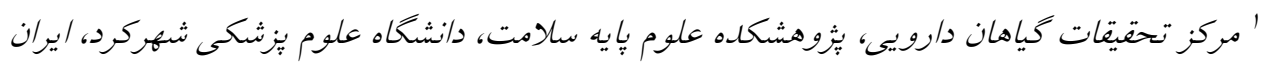

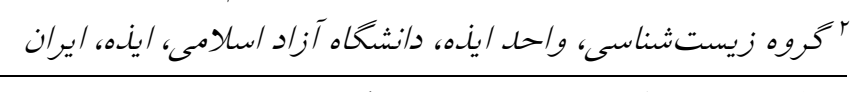

\begin{tabular}{|c|c|}
\hline جكيده & اطلاعات مقاله \\
\hline 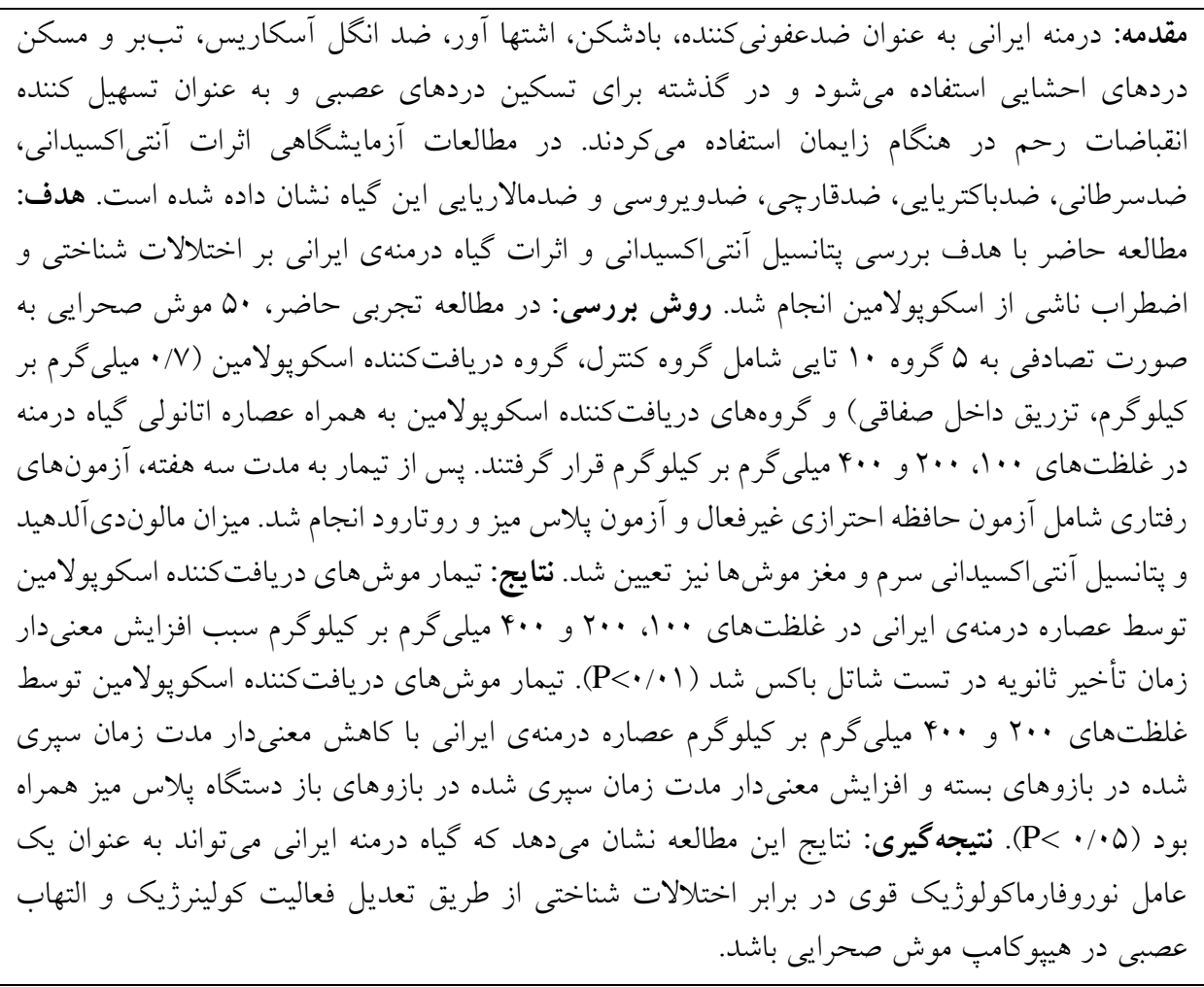 & 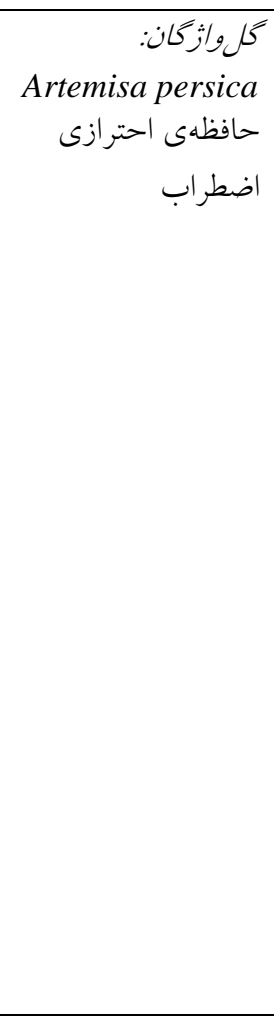 \\
\hline
\end{tabular}

Alzheimer disease (AD); Acetylcholinesterase (AChE); Superoxide dismutase (SOD); Glutathione peroxidase : مخفنها (GPx); Catalase (CAT); Choline acetyltransferase (ChAT); brain-derived neurotrophic factor (BDNF) doctor.setorgi@gmail.com : نويسنده مسؤول:

doi: $10.29252 /$ jmp. 1.73 .133

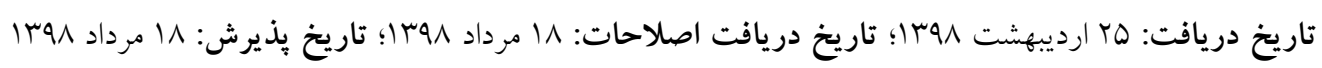

(c) 2020. Open access. This article is distributed under the terms of the Creative Commons Attribution-NonCommercial 4.0 International License (https://creativecommons.org/licenses/by-nc/4.0/) 